\title{
TRIALS AND TRIBULATIONS IN LONDON BELOW
}

\author{
IRINA RAT, Ă \\ “Dunărea de Jos" University of Galați \\ Rata.irina@gmail.com
}

Recibido: 07-05-2017

Aceptado: 14-10-2017

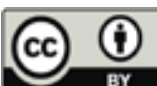

\section{ABSTRACT}

Neil Gaiman is a highly acclaimed British author of novels, short fiction, film scripts, graphic novels, and radio plays. His first novel, Neverwhere, was his attempt to fill in the blanks left by the television series with the same name, by writing down, everything that he could not fit into the restrictive television format. This paper analyses the novel through the lens of structuralism and poststructuralism, in order to reveal inherent social critique, artfully concealed in a game of complex urban imagery, chronotopic structures and intertextual references.

KeY wORDS: urban fantasy, urban hell, intertextuality, chronotope, Neverwhere, Neil Gaiman

\section{RESUMEN}

Neil Gaiman es un aclamado autor británico de novelas, relatos breves, guiones cinematográficos, novelas gráficas y obras para la radio. Su primera novela, Neverwhere, fue su intento de rellenar los espacios en blanco de la serie de televisión con el mismo nombre, añadiendo todo lo que no podía encajar en el restrictivo formato televisivo. Este artículo analiza la novela a través de la óptica del estructuralismo y el postestructuralismo, con el fin de revelar la crítica social inherente, oculta artísticamente bajo un un juego de imágenes urbanas complejas, estructuras cronotópicas y referencias intertextuales.

Palabras clave: lo fantástico urbano, intertextualidad, cronotopo, Neil Gaiman. 
Neil Gaiman is considered «one of the core, canonical authors in several fields of literary study, including, but certainly not limited to: science fiction and fantasy, comic studies, and children's literature» (Eveleth \& Wigard, 2016: 3). Neverwhere is an Urban Fantasy set in the nineties London, affected by complex issues of the post-Thatcherite era, such as poverty, inequality, unemployment, and homelessness, which were a direct result of the deindustrialization, monetarism, austerity, and misguided government policies (Cassidy, 2013). All of these issues find their way into Gaiman's prose and become inherent to London in the novel. Gaiman is not unique in this respect, because starting with the industrialisation era and to this day, cities are a major part of our lives and thus have been increasingly featured in literature and cultural production in general.

According to the United Nations Department of Economic and Social Affairs, in 2014, 82 per cent of the population was living in urban areas in Northern America, and 73 per cent in Europe; with an estimated 66 per cent of the world population to become urbanized in 2050 (2014: 1). This process of urbanisation is historically associated with important economic and social transformations, with changes in population health, employment, life expectancy, literacy, etc. Therefore, the city is firmly established in the everyday life and background at the end of the $20^{\text {th }}$ century and the beginning of the $21^{\text {st }}$ century. It emerges in every aspect of today's culture, it can be located in literature, theatre, music, and cinema, depicted either in a positive or negative light, since the city is both a «cultural product», and a "producer of culture» (Krätke, 2006: 325). The city in literature has been represented as a «palimpsest of its history, a story written in the layout of streets, squares, and roads» (Gomel, 2014: 173); being «the urban jungle, as a place that is ripe for colonising, missionazing and civilizing strategies» (McLaughlin, 2000: 21); and as «the urban hell», disguised as heaven, representing the urban underworld underneath the urban splendour (Buck-Morss, 1995: 93 qtd. in Kaika, Swyngedouw, 2005: 350); seen as a «theatre in which wrongness can be sensed brooding», as it is represented in Dickens (Westfahl, 2005: 853); or as «a state —of mind, of taste, of opportunity (...) where ideas are traded, opinions clash and eternal conflict may produce eternal truths» (Caen, 1967). Some of the aforementioned concepts of the city in literature can also be encountered in Gaiman's prose. In mainstream literature of today, almost every genre contains urban subgenres, such as: Urban Fiction, Urban Crime Fiction, Urban Fantasy, Urban Gothic, etc.

However, the city is notoriously difficult to depict, due to the complexity of urban environments on the one hand, and to the effects of the deteriora- 
tion of urban socio-economic conditions, on the other hand. While there are numerous positive changes brought about by urbanisation, negative effects can also be identified, because «urban areas are more unequal than rural areas and hundreds of millions of the world's urban poor live in sub-standard conditions» (United Nations, 2014: 3). Thus, most of the time in Urban Fantasy, when it is not the setting of some sort of supernatural events, or a character in its own right, it is the vehicle for social commentary directed at all the negative aspects of urbanisation and urban in general.

The origins of Urban Fantasy are traced back by Clute to Dickens and Sue. He states that «(they) both tended to imagine internal kingdoms within the city (...) which operated as microcosms and parodies of the larger reality» (Clute \& Grant, 1999: 975). Their models were further developed and today Urban Fantasy writings:

tend to crosshatch the mundane world with otherworlds, often locating within cities the portals through which such intermixings are announced; they tend to emphasize the consanguinity not only of intersecting worlds, but of peoples, times (timeslip; time travel) and stories (urban legends) as well; they tend (...) to treat the late $20^{\text {th }}$ century as an essentially urban drama, so that conflicts within the city resonate throughout the worlds; and, like most fantasies, tend to try to achieve a sense of healing (Clute \& Grant, 1999: 976).

Urban Fantasy takes place in a city, yet what makes it specifically urban is the fact that it encompasses «whole universes of discourse within the borderlands» (Westfahl, 2005: 852). This is mainly the reason why most urban fantasies are set in complex, multilayered, real cities, because it is difficult to build a fantastic space as complex as a real city. There is a limited number of real cities that are used in Urban Fantasy. These are mainly cities employed in other stories before; cities that have a complex imagery in literature. According to Westfahl, such cities are: London, New York, Paris, Venice, Los Angeles, San Francisco, New Orleans, Prague, Berlin — «cities already haunted in our minds' eyes by previous tales» (2005: 853). They present the city, as an urban labyrinth, where life aboveground and life underground intersect, employing the «as-above-so-below structure of the city» (Westfahl, 2005: 853). All these urban fantasies are "fantastic re-enactments of the drama of the city», and «taking literally certain urban metaphors» (Westfahl, 2005: 853). As stated by Westfahl: «the personal dramas of the protagonists in urban fantasy tend to echo its fundamental vision of the city-world as being savagely divided, but also organically one thing» (2005: 853). These dramas depict the struggles 
of their protagonists to survive in the modern city, in a modern continuation of Dickens and Sue tradition.

When it comes to Postmodern Fantasy, it is characterized by a non-linearity of time, and dwelling on the narrative possibilities of parallel worlds and plural truths. These parallel worlds defy the Newtonian-Euclidean paradigm of homogenous, uniform, three-dimensional spatiality and linear, chronologic temporality, creating, what Gomel calls impossible chronotopes (2014: 29). Chronotope, according to Bakhtin, is «the intrinsic connectedness of temporal and spatial relationships that are artistically expressed in literature» (2008: 84). Gomel in Narrative Space and Time (2014) considers Bakhtin's theory and discusses five ontological strategies used for the creation of impossible chronotopes that determine the final shape of the «storyworld» (2014: 28): layering, flickering, embedding, wormholing, and collapsing. When it comes to a general classification of chronotopes used in Fantasy fiction, Nikolajeva (2003) proposes a classification of Fantasy novels according to their motifs and specific chronotopes into three types of chronotopes: multidimensionality or transition between chronotopes, time distortion, and heterotopia (a multitude of discordant universes) (2003: 141-145). All of the aforementioned chronotopes not only determine the shape of the storyworld, but also play a far more important role in Fantasy fiction, for instance, the city in Urban Fantasy may take on flesh and become a character in the novel. Gaiman's fictional worlds are characterized by heterogeneity and complexity, since they do not use a single chronotope, but rather merge multiple chronotopes in a single novel. According to Bakhtin, «chronotopes are mutually inclusive, they co-exist, they may be interwoven with, replace or oppose one another, contradict one another or find themselves in ever more complex interrelationships» (Bakhtin 2008: 252). The subsequent analysis will look into the chronotopic structure emerging from the analysed novel.

Gaiman's works are also renowned for exhibiting extensive intertextuality, combining the literary tradition with popular culture, represented by myth, traditional and modern folklore. The term intertextuality was coined Kristeva in her essay, «Word, Dialogue and Novel» in 1966, in discussing Bakhtin's concept of dialogism. She uses it «to designate the various relationships that a given text may have with other texts» (Baldick, 2001: 128). It is further developed by many twentieth century literary theorists like Barthes, Derrida, Riffaterre, Genette, Culler, and others. It is a flexible concept, used by structuralists (Genette, Riffaterre) to locate and fix literary meaning, and by poststructuralists (Barthes, Derrida) to disrupt notions of meaning (Allen, 2000: 4). As defined by Kristeva, 
intertextuality is «a mosaic of quotations; any text is the absorption and transformation of another» (1986: 37). These texts are made up of «the cultural (or social) text», which includes all the different discourses that make up what we call culture (Allen, 2000: 36). Gaiman uses a large number of sources in his works, reinterpreting and reimagining them, and giving them a new purpose and scope. These intertextual allusions allow a dialogue between their sources and the novel, further and facilitate the comparison and contrast between them, bringing additional layers of meaning to narration, and painting vivid images in reader's imagination, making the story more relatable in the process.

Neil Gaiman's Neverwhere (1998) is often given as a perfect example, «a paradigm» of Urban Fantasy genre (Beaudry, 2012: 71). It is also a «portal-quest fantasy» (Mendlesohn 2008: 38), set in the nineties London. It deals with the adventures of Richard Mayhew in the London Underground, where live those "who fell through the cracks of the world» (Gaiman, 2015: 135). Neverwhere is the novelisation of the television series Neverwhere, written by Neil Gaiman with the assistance of Lenny Henry, which was aired by BBC Two in 1996. Gaiman published it in novel form two years later. The inspiration for Neverwhere, as Gaiman acknowledged, came to him after he had read Wolfe's novel Free Live Free (1999), set in Chicago, and which features a magical realm hidden in the familiar urban setting. In Free Live Free, one of the main characters is named Madame Serpentina, so Gaiman acknowledges Wolfe's influence, by using the name Serpentine for one of the Seven Sisters in Neverwhere. In addition, Serpentine is also one of minor tributaries of the Thames, and the leader of Amazon-like warriors (Beaudry, 2012: 72). This idea was further developed in a discussion that Gaiman had with the comedian and actor Lenny Henry, «who suggested the concept of tribes of homeless people living beyond the notice of 'ordinary' people in London» (Barnett, 2017).

The novel begins with two epigraphs. The first one is a quote from Chesterton's The Napoleon of the Notting Hill (1904), while the second epigraph is a fragment from an excerpt from The Lyke-Wake Dirge. Since Chesterton's The Napoleon of Notting Hill is set in an alternate reality London, and critiques London's society at the beginning of the twentieth century, it is obviously another source of inspiration for Gaiman. There are a number of similarities between the two novels that reinforce their connection and help the reader, aware of Chesterton's novel to interpret Neverwhere. For instance, both novels portray London as a city organized in boroughs, baronies and fiefdoms, populated by an assortment of odd characters dressed in archaic garments. Both novels present a social critique of the multicultural London's society. 
When it comes to The Lyke-Wake Dirge, it is a traditional song sung during the vigil held over a dead person, in which the soul's travel from earth to purgatory is described, along with the dangers it faces on the way (Quiller-Couch, 1918: 381). And it can be interpreted as a pointer to Richard's «death» in London Above and his subsequent «rebirth» in London Below, as the Warrior, after slaying the Great Beast of London. Richard Mayhew, the protagonist's name serves a double onomastic allusion. Firstly, it is the first name of the Victorian urban sociologist Henry Mayhew, who wrote London Labour and the London Poor (1851), a study that explores London's poor and destitute. The Sewer Folk in the novel were inspired by Mayhew's «purefinders» and «mudlarks»: «Garbage! Trash! Offal! Debris! Come and get it! Nothing whole or undamaged! Crap, tripe, and useless piles of shit. You know you want it» (Gaiman, 2015: 118). Secondly, Richard or Dick, is a reference to Sir Richard - Dick Whittington (four times Lord Mayor of London), and to the folktale Dick Whittington and His Cat. Marquis de Carabas takes his name from the main character of Perrault's fairytale Puss in Boots, becoming a means to Richard's ascension in London Below. Just like the quick-witted cat from Puss in Boots, Marquis de Carabas embodies the cleverness and resourcefulness of somebody, who provides services by trickery and deceit for a living. In the novel, he secures the promise of a favour from Door, which could come handy to somebody who tricks and cheats for living, because she can open any «door» in time and space, thus giving him the perfect escape route in time of need.

Other onomastic allusions present in the novel belong to Lady Door's family. Starting with her mother's name - Portia, her sister's name - Ingress, her brother's - Arch, and her father's - Portico, to the entire House of the Arch, all are references to the ancient architectural elements of a building. On the one hand, all of them are outdated elements that are usually used in temple-fronts alluding first to their noble origins, and second to the fact that they are extinct (all family members are dead). On the other hand, their names suggest their abilities to open portals or «doors» through dimensions. Lady Door is the only member of the family that is still alive, as a reference to the fact that door is the sole feature still in use today. Another such allusion is in the name of one of the secondary characters - Old Bailey, which is a reference to Criminal Court of England and Wales, or one of the buildings housing the Crown Court, also commonly known as the Old Bailey. Old Bailey in the novel is as old as London itself; his name is a reference to his knowledge, as he sells information: «You wants it, we knows it» (Gaiman, 2015: 122). Incidental- 
ly, he is the one who brings the Marquis back to life, thus serving as a metaphor for the workings of the criminal justice system, as the Marquis was killed by Croup and Vandemar, two hired assassins. Some other onomastic allusions like: Hunter, Rat-Speaker, Mr. Whiskers, Lamia, Dagvard (Anglo-Saxon: dayguard), Master Longtail, etc. literally reference the abilities, traits or occupations, reinforcing their characters.

The novel is a social allegory with numerous fantastic elements, which criticises modern society. Both London Labour and the London Poor and The Napoleon of the Notting Hill observe and describe the society during their corresponding periods. Neverwhere, in its turn, recounts the urban experience in the nineties London and critiques the attitude of society towards the poor and destitute during post-Thatcherite period, with its increased unemployment and homelessness (Roger 2013). In the novel, the metaphor of invisibility of the poor and homeless is literalised. Richard becomes invisible to everybody, and as a result becomes homeless and jobless after helping Door. When Richard and Jessica first find Door crumpled, bleeding on the ground, Jessica is unwilling to help: «Someone else will be along; someone else will help her» (Gaiman, 2015: 26). When Richard decides to help Door, Jessica breaks off their engagement. She is described as a ruthless person, so much so Richard's co-worker Gary refers to her as the «Creature from the Black Lagoon» (Gaiman, 2015: 19). Her attitude towards the poor and destitute is representative for the society's attitude during the nineties: «If you pay them any attention, Richard, they'll walk all over you. They all have homes, really. Once she's slept it off, I'm sure she'll be fine» (Gaiman, 2015: 25). Jessica's depiction in the novel is that of a social climber, someone that «was certainly going somewhere» (Gaiman, 2015: 12), who reveres Mr Stockton for his status and money: «he's not just a very important man. He's also a corporate entity in his own right» (Gaiman, 2015: 22). She tries to change Richard, by seeing in him «an enormous amount of potential, which, properly harnessed by the right woman, would have made him the perfect matrimonial accessory» (Gaiman, 2015: 12). Jessica tries to influence her fiancé by bringing him all sorts of self-education titles, like Dress for Success and A Hundred and Twenty-Five Habits of Successful Men, along with «books on how to run a business like a military campaign» (Gaiman, 2015: 13), hoping to transform him into a version of herself.

In opposition, Richard is content with Jessica's attention, and even buys an engagement ring at her suggestion, without even attempting to analyse his own feelings, and to ask himself whether he actually wants to marry her. Richard's kind-heartedness makes him vulnerable, as his journey in the novel 
starts with helping a person in need, which sets about his «personal drama». He loses everything in London Above and as a result, is forced to seek entry to London Below. Losing all means of subsistence was a fairly common occurrence in the nineties London, with Thatcher reforms affecting housing and employment in a negative way, many people had lost their jobs and became homeless as a result. Therefore, when Richard helps Door, he becomes invisible to his co-workers, to his landlord, to Jessica, and even to taxi drivers. His credit card is rejected, his flat is rented to some other people, so his only choice is to look for Door and ask her for help, as she hinted it might happen. The fact that Richard ending up homeless and impoverished becomes invisible to everybody literalises the metaphor of invisibility of the poor and destitute.

At the same time Jessica's fascination with power and money, speaks volumes about societal values of the nineties: "And they weren't just people. They were People. Some of them were even Personalities» (Gaiman, 2015: 195), states Jessica, referring to the rich and famous attending Mr Stockton's exhibition. There are numerous examples in the novel opposing the rich and the poor, like menu options, dwellings, clothing and accessories. All these allusions are used as pointers towards text interpretation, and as means to anchoring it. For instance, in the following fragment: «Clarence was talking to someone on his portable phone, a slimline piece of foldout engineering that made the Star Trek communicators look bulky and old-fashioned. He turned it off, pushed down the antenna, put it into the Armani pocket of his Armani suit, where it did not even make a bulge» (Gaiman, 2015: 195), where terms like «portable phone», «slimline piece», «Armani suit» indicators of their bearer's wealth, and indirectly of the financial district's wealth. In another instance, when Jessica is worried about the exhibition's outcome, Clarence, her colleague parodies gossip newspaper titles that would appear the next day, as a result of such a disaster: «I can see the headlines now (...) 'Geritol Billionaires Crush Marketing Babe in Museum Canapé Dash Horror'» (Gaiman, 2015: 114). The allusions: Geritol (an American trademark of dietary supplement), «marketing babe» and «canapés» are commentaries on the preoccupations of Mr. Stockton's exhibition attendance, on the sensationalised headlines of gossip magazines, and on the triviality of their subjects, as well as, on their reader's interests.

These references are reinforced by the numerous menu options for the rich and famous at Stockton's exhibition: «'And sparkling mineral water?' (...) 'What about plain mineral water?'»(Gaiman, 2015: 194); «the grumbling of journalists and celebrities who could smell the canapés, vol-au-vents, sundry 
nibbles, and free champagne» (Gaiman, 2015: 194); along with: «with a paper plate heaped high with chicken legs, melon slices, mushroom vol-au-vents, caviar puffs, and small venison sausages (...) with a Brie and fennel sandwich and a glass of freshly squeezed orange juice»(Gaiman, 2015: 200). All these numerous menu options are opposed to the poverty of the inhabitants of London Below. Not all of the inhabitants of London Below are described as dirt poor, some of them are well off compared to others, however, the majority of them have limited menu options. For instance, when Richard is upset that Anaesthesia ate all of his fruits, she asks him if he likes cat. Richard's confirmation is followed by: «Anaesthesia looked relieved. 'Thigh?' she asked. 'Or breast?'» (Gaiman, 2015: 86). Her offer shocks Richard, who never imagined cats as food. Later, at the Floating Market, when Old Bailey tries to sell him some boiled rook, Richard is no longer dismayed by the offer, but takes it in stride.

The people inhabiting London Below either were born there or ended up there, because of their personal tragedies, as it is Anaesthesia's case, who ran away after suffering abuse in her aunt's house. They do not use money, but barter one thing for another. However, in order to survive one has to have something to swap. As a result, most of them struggle to survive. When Anaesthesia first ended on the streets she was: «stealing bread an' milk off people's doorsteps to eat. Hated doing that so I started hanging around the street markets, taking the rotten apples an' oranges an' things people threw away» (Gaiman, 2015: 95). The lack of bread and milk, which are considered everyday staples, and the ingestion of rotten fruit are allusions to extreme poverty and destitution. The extreme poverty of some of the inhabitants of London Below is represented by Sewer Folk, who scour the sewers for all sorts of junk to sell, including dead bodies, as it was seen in the case of Marquis de Carabas.

Once people end up in London Below, they cannot ever return, as Anaesthesia states, when Richard asks her if she does not want back «to the real world», "You can't. It's one or the other. Nobody ever gets both» (Gaiman, 2015: 95). Every character living in London Below is affected by its ever-changing, jumbled spatio-temporality. Some characters appear to be several hundred years old, while others are of an uncertain age, just like the people living on the streets, who lack the basic personal hygiene items and access to clean water. The inhabitants of London Below are feudally organised in baronies, fiefdoms like: The Raven Court, The Sewer Folk, The Mushroom People, The Earl's Court, The House of Arch, The Elephant and The Castle, Rat-speakers, etc. These are all bound by fealty and loyalty, as Richard observes studying the crowds: 
There was something deeply tribal about the people, Richard decided. He tried to pick out distinct groups: there were the ones who looked like they had escaped from a historical reenactment society; the ones who reminded him of hippies; the albino people in gray clothes and dark glasses; the polished, dangerous ones in smart suits and black gloves; the huge, almost identical women who walked together in twos and threes, and nodded when they saw each other; the tangle-haired ones who looked like they probably lived in sewers and who smelled like hell; and a hundred other types and kinds (Gaiman, 2015: 120).

The way people inhabiting London Below are organised mirrors the separation or even segregation of people in London Above. They are organised economically, culturally, professionally, racially, etc.

When it comes to its spatio-temporal aspect, London is presented in the novel as a «simultaneous city» resembling Freud's Rome (Gomel, 2014: 181), since the past and present co-exist in the same space: new steel and glass structures neighbouring historic buildings and monuments. As it can be seen in the following example: «it was a city in which the very old and the awkwardly new jostled each other, not uncomfortably, but without respect; a city of shops and offices and restaurants and homes, of parks and churches, of ignored monuments and remarkably unpalatial palaces» (Gaiman, 2015: 9). However, structurally London is layered in strata, as London Below is situated in the London Above's Underground. This structure echoes Christian cosmology with Heaven and Hell opposing each other, and the human world in the middle (Lutwack, 1984: 39). Consequently, a structure with Heavens on top, the human world represented by London Above, and London Below associated with Hell, can be recognized in the novel. It is reinforced by the numerous allusions to the Bible, strengthening this opposition between London Below and London Above.

The oppositions between London Above and London Below contrast the two planes, accentuating the city's vertical structure. The entire novel is based on a set of binary oppositions: the rich are opposed to the poor, the homeless to the homeowners, the unemployed to those earning a living, or in other words: London Above is opposed to London Below. In Neverwhere the human world is not devoid of its flaws, and London Below is the prison of the fallen Angel Islington, which draws a parallel with Lucifer's dwelling in Hell. Thus, London Below can be compared to an urban hell. Where London Above is clean, orderly, safe, regulated, London Below is dirty, disorderly, unsafe, and unregulated. London Above is inverted and contested in London Below. 
An example of such an inversion and contestation is the novel's antagonist angel Islington, who turns out to be the personification of Lucifer, «the fallen angel». The two images of the angel represent the two sides of the same coin. In the beginning Islington is «an angel of astonishing, perfectly androgynous, beauty» (Gaiman, 2015: 273) and later his image is inverted, as «the angel's serene beauty cracked; its eyes flashed» (Gaiman, 2015: 345). «The angels I have in mind are all wings, haloes, trumpets, peace-on-earth-goodwillunto men» (Gaiman, 2015: 146), and: «The Angel Gabriel? Raphael? Michael?» (Gaiman, 2015: 146); or as in: «'You said, Lucifer was an angel'. Islington smiled superciliously. 'Lucifer?' it said. 'Lucifer was an idiot. It wound up lord and master of nothing at all'» (Gaiman, 2015: 345), alluding to Islington's intention to escape his prison and reign in Heaven. It is portrayed as a highly likable character at first, his kindness being taken for granted, implied by his celestial origins, only to be contrasted later by the depth of his wickedness and corruption. For instance, when Islington was dreaming of the things he had done to the four million people inhabiting Atlantis in the novel, he saw that «nothing of Atlantis remained but the water-bloated bodies of children, of women and of men, floating on the cold morning waves; bodies the seagulls, gray and white, were already beginning to pick with their cruel beaks» (Gaiman, 2015: 272). When Door blamed the angel for the death of millions, «it screamed at them, crazy-scary and uncontrolled, utterly certain in its righteousness, 'They deserved it'» (Gaiman, 2015: 346), expressing no remorse for killing them. As it turns out, Door's family was killed at Islington's orders, in an egoistic attempt to slay them for his own benefit: «'Not for me the smooth agonies of adulation, of hymns and halos and self-satisfied prayers', it said. 'I have ... my own agenda'»(Gaiman, 2015: 348). He justified the killing as a means to obtaining his goals: «Soon, all the rewards your revolting little minds can conceive of will be yours. When I have my throne» (Gaiman, 2015: 351); and he promises the ultimate reward to those helping him escape his prison: "'Have no fear', it said. 'For when the vastness of creation is mine, and they gather about my throne to sing hosannas to my name, I shall reward the worthy and cast down those who are hateful in my sight'»(Gaiman, 2015: 352). While Satan or Lucifer is a Gothic motif, in Gothic literature it is portrayed as a Promethean figure rebelling against authority and oppression, rather than being the «father of lies». In postmodern fantasy his «good» image is deconstructed, returning to its classical, biblical portrayal. This seemingly unrelated deconstruction of the angel image actually reinforces the sense of duality of London's image created in the novel. 
This and other numerous Biblical allusions allow a dialogue between the Bible and the novel, accentuate the oppositions between the two Londons. Another such an example is in the following reference «I tried to be a Good Samaritan» (Gaiman, 2015: 143), an allusion to The Parable of the Good Samaritan told by Jesus, from the Gospel according to Luke, from The New Testament, which is meant as a critique to the way society treats poor and destitute. Another is «thirty pieces of silver», when Hunter betrays Richard and Door, and as a result receives her payment for betrayal, Richard casually asks her if she received her «thirty pieces of silver», which is a reference to Judas Iscariot's betrayal from The New Testament, from the Gospel according to Luke. However, unlike Islington, Hunter feels guilty for betraying them and atones for her «sins» by handing the spear to Richard, so he is able to defeat the Beast of London. It was inspired by the urban legend of the beast of London, widely popular during the nineteen century that of the «Black Swine of Hampstead» (Boyle, 1989). However, the image of a warrior slaying the beast also references the legend of Saint George and the Dragon, popular in medieval times. These allusions allow a dialogue between their sources and the novel facilitate the comparison and contrast between them, bringing additional layers of meaning to the narration, and painting of vivid images in the reader's imagination, making the story more relatable in the process.

There are numerous other literary and cultural allusions in the novel contributing to the city's identity, structure and meaning formation and reinforcement, as Gaiman's novels are renowned for their reliance on the rich literary tradition in the form of references to poetry, prose, as well as popular culture (myth, traditional folklore and modern, contemporary folklore). References to folklore and ancient mythology: trolls, pixies, labyrinth and the beast in it (allusion to Minotaur's labyrinth), Cyclopes, Lamia (a child-eating demon from Greek mythology), Tower of Babel, etc. paint vivid images, add layers of meaning, e.g.: «The street ended in a vast Cyclopean gateway - built of enormous rough stone blocks. Giants built that gate, (...) half-remembered tales of longdead kings of mythical London (...) tales of King Bran and of the giants Gog and Magog, with hands the size of oak trees, and severed heads as big as hills» (Gaiman, 2015: 324); and: «Before King Lud founded the village on the Thames marshes, there was a labyrinth here» (Gaiman, 2015: 325). These add a mythical dimension to the city, which along the historical (which is also temporal) and spatial dimensions create a tridimensional complex city structure.

When Richard first arrived in London from Scotland, he was «surprised to find it filled with colour» (Gaiman, 2015: 9), expecting it to be «a gray» or 
even «a black city». At first, he found London: «huge, odd, fundamentally incomprehensible, with only the Tube map, that elegant multicolored topographical display of underground railway lines and stations, giving it any semblance of order» (Gaiman, 2015: 10), but then he progressively acquired a comprehension of the city through «white knowledge». A process that makes him become aware of the fact that «the actual City of London itself was no bigger than a square mile, stretching from Aldgate in the east to Fleet Street and the law courts of the Old Bailey in the west, a tiny municipality, now home to London's financial institutions, and that that was where it had all begun» (Gaiman, 2015: 10). Gradually, Richard realizes that «London grew into something huge and contradictory» (Gaiman, 2015: 11), and that «the Tube map was a handy fiction that made life easier but bore no resemblance to the reality of the shape of the city above» (Gaiman, 2015: 10). The «actual» City of London, "where it all begun», became a «cold and cheerless place of offices» (Gaiman, 2015: 10), a simulacrum (Baudrillard 1988: 166) of financial success, prestige, and a symbol of money. In the words of Old Bailey, who, observing the city, reminisces about the time when the «actual» London was more than «glass and steel» buildings:

Old Bailey remembered when people had actually lived here in the City, not just worked; when they had lived and lusted and laughed, built ramshackle houses one leaning against the next, each house filled with noisy people. Why, the noise and the mess and the stinks and the songs from the alley across the way (then known, at least colloquially, as Shitten Alley) had been legendary in their time, but no one lived in the City now. It was a cold and cheerless place of offices, of people who worked in the day and went home to somewhere else at night. It was not a place for living anymore. He even missed the stinks (Gaiman 2015: 176).

This fragment talks about a different London: a «dirty», «smelly», «noisy» place in opposition with «cold and cheerless» financial institutions. This London does not exist in London Above anymore; however, nothing ever disappears in London, and everything lost and forgotten can be found in London Below. In this unseen, hidden London modern technology does not work and it is replaced by magic and alternate temporality and spatiality rules.

London in Neverwhere has a duplicitous nature, exemplified in the following lines: «young man (...) understand this: there are two Londons. There's London Above - that's where you lived - and then there's London Below - the Underside - inhabited by the people who fell through the cracks in the world» (Gaiman, 2015: 135). London Above resembles Dr. Jekyll with its respectabili- 
ty, orderliness, cheerlessness and coldness, while London Below resembles Mr. Hyde, since all of the lost and forgotten history, traumata, places and people are hidden away in London Below; which is: «built of lost fragments of London Above: alleys and roads and corridors and sewers that had fallen through the cracks over the millennia, and entered the world of the lost and the forgotten» (Gaiman, 2015: 326). While this opposition between Primary and Secondary world are specific to the transition between chronotopes (Nikolajeva, 2003: 142), however, as can be seen from the above examples, time and space are warped in London Below. It functions as a repository, of historical events and traumata, because «the city is a palimpsest of its history», and it is «haunted by the memory of the cataclysm and the premonition of its return» (Gomel, 2014: 173). This can be exemplified by the following example encountered in London Below: «"pea-soupers", (...) London Particulars. Thick yellow river fogs, mixed with coal-smoke and whatever rubbish was going into the air for the last five centuries. (...) We get the ghosts of them down here. (...) Not ghosts. More like echoes» (Gaiman, 2015: 243); or «there had been Sewer Folk before the Great Stink, of course, living in the Elizabethan sewers, or the Restoration sewers, or the Regency sewers» (Gaiman, 2015: 282). It is also a repository of myths, as in: «Giants built that gate, thought Richard, half-remembered tales of long-dead kings of mythical London churning in his head, tales of King Bran and of the giants Gog and Magog, with hands the size of oak trees, and severed heads as big as hills» (Gaiman, 2015: 324); and legends, like the urban legend of the «Black Swine of Hampstead», widely popular during the nineteenth century (Boyle, 1989):

they say that back in first King Charlie's day (...) before the fire and the plague, this was, there was a butcher lived down by the Fleet Ditch, had some poor creature he was going to fatten up for Christmas. Some says it was a piglet, and some says it wusn't, (...) that wusn't never properly certain. One night in December the beast runned away, ran into the Fleet Ditch, and vanished into the sewers. And it fed on the sewage, and it grew, and it grew. And it got meaner, and nastier. They'd send in hunting parties after it, from time to time (Gaiman, 2015: 178).

London Below is built around the structure of the London Underground system; however, its places and spaces are not limited to London Underground. The Tube serves as the connection between the two Londons. This connection is permanent; it is never completely severed as the two cities co-exist in the same space and in the same time, and as a result the «access to them is intermittent and privileged, a function always of someone leaving 
and intruding into the mundane world» (Mendlesohn, 2008: 151). In fact, London Below exhibits a jumbled spatiality and temporality: «There are little pockets of old time in London, where things and places stay the same, like bubbles in amber (...) there's a lot of time in London, and it has to go somewhere -it doesn't all get used up at once» (Gaiman, 2015: 244); or «there were a hundred other little courts and mews and alleys in London just like this one, tiny spurs of old-time, unchanged for, three hundred years. Even the smell of piss here was the same as it had been in Pepys's time, three hundred years before» (Gaiman, 2015: 86). This time and space distortions introduce the time distortion chronotope (Nikolajeva, 2003: 142). For example, a Roman legion coexists with a Victorian hospital, Blackfriars abbey, and the Tube. Another such example is the tube carriage housing a medieval court - the Earl's Court, where are stored lost and found possessions of the Underground's travellers. The Earl of the Earl's Court is surrounded by a jester, a falconer, a lute player and men at arms. He wears a fur-lined dressing gown and carpet slippers, while offering his guests Cadbury's Fruit and Nut chocolate bars and Cokes. The coexistence of all these opposed, heterogeneous elements is realised through the strategy of collapsing, and this type of chronotope is termed as the black hole chronotope by Gomel (2014: 172). Some places are not even fixed in space, but change their spatial location, as in the case of Floating Market: «'It's the Floating Market, silly. (...) It moves. Different places. Last one I went to was held in that big clock tower. Big ... someone. And the next was'Big Ben?' he suggested»(Gaiman, 2015: 107). This non-linear spatio-temporality is symbolised so eloquently by juxtaposing the adverbs «never» and «nowhere» in the novel's title. Another instance of non-linear spatio-temporality is the location of Down street in London Below: "And beneath that, in smaller letters: Down street. Please knock. 'you get to the street through the house?' (...) 'no' (...) 'the street is in the house'» (Gaiman, 2015: 306).

When it comes to «as-above-so-below» structure of the fantastic city, London Below mirrors closely London Above. As stated by Clute: «in fantasy, what is underground may also explicitly mirror that which is open to the air: most fantasy edifices show some vertical symmetry, with towers being echoed by underground structures»(Clute \& Grant, 1999: 973). Such underground structures like the Tower of Babel, the labyrinth, the Great Hall, the Cyclopean gateway, etc. echo the towers, skyscrapers, and buildings from London Above. The entire London Above is contested and inverted in London Below. For instance, the «cold and cheerless» and orderly financial district is in vivid contrast to the Floating Market: 
It was loud, and brash, and insane, and it was, in many ways, quite wonderful. People argued, haggled, shouted, sang. They hawked and touted their wares, and loudly declaimed the superiority of their merchandise. Music was playing - a dozen different kinds of music, being played a dozen different ways on a score of different instruments, most of them improvised, improved, improbable. Richard could smell food. All kinds of food-the smells of curries and spices seemed to predominate, with, beneath them, the smells of grilling meats and mushrooms. Stalls had been set up all throughout the shop, next to, or even on, counters that, during the day, had sold perfume, or watches, or amber, or silk scarves. Everybody was buying. Everybody was selling (Gaiman 2015: 118).

Such unbelievable items like «fresh dreams», «first-class nightmares», «crap, tripe, and useless piles of shit», «lost property» (Gaiman, 2015: 118), etc. are on sale in this controversial, loud, dirty and dynamic place. The Floating Market is a «carnivalesque» space, subjected to «a temporary suspension of all hierarchic distinctions and barriers among men and of certain norms and prohibitions of usual life» (Bakhtin, 1984: 15). It also brings a temporary equality of speech to different social classes, thus encouraging free interaction, which also implies a degrading familiar speech specific to the marketplace (Bakhtin, 1984: 152). It has a festive character, and it is characterised by grotesque realism (Bakhtin, 1984: 153), expressed in the descriptions of the people and their stalls, buying and selling at Floating Market. The Market that Richard visits is located at Harrods, parodying the luxury department store, inverting it in the carnival-time chronotope that is «animated and illuminated by the ancient public square's spirit of carnival and mystery» (Bakhtin, 2008: 249). The luxury, sterility and orderliness of Harrods are contested by the carnivalesque marketplace, represented by the Floating Market.

The Floating Market is also a heterotopia, which according to Foucault is a counter-site, «a kind of effectively enacted utopia in which the real sites, all the other real sites that can be found within the culture, are simultaneously represented, contested, and inverted» (1984: 3). It exhibits «a sort of simultaneously mythic and real contestation of the space in which we live» (Foucault, 1984: 4). The Floating Market is not set in space or time, but rather functions according to its own set of rules, e.g. the «Market Truce». Its access is regulated, you cannot enter it unless you know where and when it is held, and in order to find it out, someone knowing it has to tell you. The entire London Below is a forbidden place for the inhabitants of London Above, which once glimpsed by them would slip their minds, being perceived as an illusion. London Below is not represented by the perfect mirrored image of London Above, but rather by 
its jumbled, distorted, inverted representation. London Below does not appear to have borders, as it is a labyrinthine space that opens into other dimensions, provided you know where the connecting points between them are, or under Door's hand. This distorted, mirrored image belongs to the chronotope of heterotopia (Nikolajeva, 2003: 143). Another such example is the labyrinth, which is not only a heterotopia, but also a heterochronia: «they walked through daylight and night, through gaslit streets, and sodium-lit streets, and streets lit with burning rushes and links. It was an ever-changing place: and each path divided and circled and doubled back on itself» (Gaiman, 1998: 190).

On the one hand, there are numerous heterotopias in London Above: British Museum, National Gallery, Big Ben, Tower of London, etc. And on the other hand, the entire London Below is a heterotopia, a contested and inverted non-space, a forbidden, with restricted access space, gathering time (Foucault 1984), and exhibiting "whole universes of discourse within the borderlands» (Westfahl, 2005: 852). Even the place names are affected by this contestation and inversion. For example: Earl's Court becomes literally a medieval court in a train car; Angel and Islington become Angel Islington, the «fallen angel» imprisoned in the «Hell» of London Below. Knightsbridge becomes Night's Bridge, a place where «nightmares» dwell and take a toll for crossing. Life in London Below, among «rat speakers», «rats», «shepherds», «mushroom people», etc. is no easy feat, as there are dangers, trials and a price to pay. All the trials and tribulations described in the novel are metaphors for the struggles of those sleeping rough on the city streets. For example, the above mentioned Night's Bridge is a metaphor for depression, as people crossing the bridge are assaulted by «nightmares» that «come out when the sun goes down, since the cave times» (Gaiman, 2015: 111). Richard sees his worst memories in crossing, but also has a vision of the fallen angel, which serves as an omen; and a vision of his fight with the Beast, which in this nightmare ends with his death. This display of Richard's worst memories and worst fears is metaphorically expressed in the following lines: «night is happening (...) now is the time to be afraid of the dark» (Gaiman, 2015: 111), as «night» and «dark» here symbolize depression. Anaesthesia, Richard's companion, is not strong enough to resist when crossing the bridge, and consequently succumbs to the darkness below. Another such example is the «Ordeal of the Key». This trial in itself is a metaphor for the mental illness and suicide, as Richard is assaulted by visions from London Above encouraging him to end his life. These try to confuse him on the Blackfriars line station: «new messages: end it all, was one of them. Put yourself out of your misery. Be a man-do yourself in. Have a fatal accident 
today» (Gaiman, 2015: 265). Not only places symbolize the dangers of London Below, but characters also become metaphors and symbols. «Mind the Gap» warning literally transforms into a predatory beast, called the «Gap» that preys on unsuspecting travelers pulling them into the gap, which is another metaphor for depression and suicide.

A further example of such dangers awaiting in London Below is the supernatural pair of assassins Croup and Vandemar. Mr. Croup is a metaphor for disease, as his name sounds like «croup, a pathological disease of the larynx, (...) characterized by (...) a hoarse, brassy cough» (American Heritage Dictionary of the English Language). He is a shrewd, pretentious and a verbose individual. His opposite is Mr. Vandemar, a brutish, bloodthirsty, dimwitted person, serving as a metaphor for gratuitous violence. Both of them represent the dangers of sleeping rough in London's Underground. Even the infamous Beast of London can be seen as a literalized metaphor. Depression, mental illnesses are risks caused by the sense of alienation and isolation to which those living in the city are exposed to, and which can be overcome with the help of friends. For instance, when Marquis is killed by Croup and Vandemar, the only reason he is resurrected is the fact that he left his most prized possession with his friend, Old Bailey.

When it comes to Richard, his good deed in London Above is repaid multiple times in London Below, where he is saved numerous times by the friends he made there. Even his defeat of the Beast is possible due to Hunter's weapon and experience. In London Above, Richard has no friends, although he has co-workers, who think that he collects trolls, only because he once picked one from the sidewalk and put it on his desk; and a fiancée that sees him as «the perfect matrimonial accessory» (Gaiman, 2015: 12); while all of his relatives are in Scotland. Richard fills his days with work, rare drinks with co-workers, and trailing behind Jessica as she goes shopping. He is an average city dweller, so busy that he completely forgets about everything, getting lost in his work. Even such an important event as meeting his fiancée's employer is forgotten, in spite of the notes he left himself. As Richard states, the «events were cowards: they didn't occur singly, but instead they would run in packs and leap out at him all at once» (Gaiman, 2015: 14), thus exemplifying his state of mind. The fact that he is busy does not make him any less lonely or friendless. In opposition, London Below brings him a sense of belonging, of attachment and friends. This is the reason for his return to London Below, after trying for the most part of the novel to get back to London Above, because nothing could replace the sense of kinship that he experienced in London Below. 
Gaiman expands further the universe of London Below in the short story How the Marquis Got His Coat Back. There the reader gets familiarised with the infamous shepherds of Shepherd's Bush, with the Mushroom People, with the Elephant of Elephant and Castle, with Sewer Folk, and even to some extent with Raven Court. Some of these introduce metaphors, representing further difficulties awaiting those living on the streets. For instance, in describing the Mushroom People, Gaiman skilfully describes life with addiction: «there was (...) nothing in the four men's heads at that moment but a need to get to the Mushroom, to taste its flesh once more, to let it live inside them, to serve it, and to serve it well. In exchange, the Mushroom would fix all the things about themselves that they hated: it would make their interior lives much happier and more interesting» (2015: 435-436).

Gaiman even shows the effects of addiction on people's aspect and health, as indifference and neglect regarding their own persona settles in, with such descriptions, as «a thin, pale young woman with the complexion of day-old porridge» (Gaiman, 2015: 407), and «his hair was heavy and unwashed, and there was a general smell about him of abandoned places» (Gaiman, 2015: 409), etc. Whereas the following fragment describing the life in Shepherd's Bush: «the shepherds never made you do anything. They just took your natural impulses and desires and they pushed them, reinforced them, so you acted quite naturally, only you acted in the ways that they wanted» (2015: 424) can be interpreted in numerous ways. It can be seen as the religious sects «brainwashing» of their adepts, as political mind control of masses, or as a metaphor for the «enslavement» of workers by big corporations that work its employees to exhaustion. All of the above examples extend and reinforce the idea of city as hell. Recently, at an event at London's Southbank Centre, Gaiman confirmed that he is currently working on Neverwhere sequel The Seven Sisters, thus further expanding its universe. He stated that the changes in the world in the past twenty years, along with his work with the United Nations Refugee Agency inspired him to write a continuation to the Neverwhere story (Barnett, 2017).

To conclude, London in the novel is a multi-layered political, social and cultural structure revealing a modern metropolis, anchored in space, time, myth and history. Gaiman taps into the collective knowledge, by recycling and adapting the themes and motifs from oral and written tradition, in an intertextual game. London in the novel is affected by complex social issues, echoing a divided, but nevertheless unitary «city-world». In Neverwhere London is an urban labyrinth, replicating the «as-above-so-below 
structure of the city». The complex social issues affecting the city are skilfully described using metaphors and numerous intertextual allusions. The effects of intertextuality in Neverwhere may be summed up as it follows: leaving clues of recognisable reality for the audience; providing a critical commentary of society, without openly criticising it; engaging in a debate about what is important or dominant; offering an extra-dimension to the novel; offering to its readers the pleasure of recognition of sources, and offering new layers of interpretation; providing alternative points of view on the «reality» of the everyday life. The novel is also characterised by self-reflexivity and explicitness in most of its intertextuality, which is used as an acknowledgement of the preceding literary tradition, and as a way to ensure its dialogue with the referenced texts.

\section{BIBLIOGRAPHY}

BAKHTIN, M. M. (1984): Rabelais and His World, Indiana University Press, Bloomington. - (2008): The Dialogic Imagination, translated by C. Emerson and M. Holquist, The University of Texas Press, Austin.

BarnetT, D. (2017): «Neil Gaiman announces Neverwhere sequel, The Seven Sisters», The Guardian, Friday, from February the $17^{\text {th }}, 2017$ [online], available from <https: / / www.theguardian.com/books / 2017/ feb / 17/ neil-gaiman-announcesneverwhere-sequel-the-seven-sisters?CMP=share_btn_tw $>$ [24.02.2017].

Baudrillard, J., (1988): Selected Writings, ed. M. Poster Polity Press, Cambridge.

BeAudry, J.-S. (2012): «Apologizing to a Rat» in Bealer, T. Luria, R. and Yuen, W. (eds.), Neil Gaiman and Philosophy. Gods Gone Wild!, Open Court Publishing Company, Chicago and LaSalle.

BoyLe, T. (1989): Black swine in the sewers of Hampstead: beneath the surface of Victorian sensationalism, Viking, New York.

Caen, H. (1967): San Francisco, City on Golden Hills, Doubleday, New York.

CAssidy, J. (2013): «The Economic Case for and against Thatcherism» in The New Yorker, from April the $9^{\text {th }}, 2013$ [online], available from <https://www.newyorker. $\mathrm{com} /$ news / john-cassidy/the-economic-case-for-and-against-thatcherism> [24.02.2017].

Chesterton, G. K. (1904): The Napoleon of Notting Hill, Bodley Head, London.

Clute, J. \& J. Grant (eds.) (1999): The Encyclopedia of Fantasy, Orbit, London.

«Croup» in American Heritage Dictionary of the English Language, Fifth Edition. (2011) [online], available from <http: / / www.thefreedictionary.com/ croup > [28.02.2016].

Eveleth, K., \& J. Wigard (2016): «We Have An Obligation To Imagine: A Critical Reception Of The Work Of Neil Gaiman» in J.M. Sommers (ed.), Critical Insights: Neil Gaiman, Salem Press, Hackensack [online], available from <http: / / salempress. com/store/pdfs/ci_gaiman_samplepgs.pdf/> [28.05.2017]. 
Foucault, M. (1984): «Of Other Spaces: Utopias and Heterotopias», Architecture /Mouvement/ Continuité, [online], available from <http://web.mit.edu/allanmc/ www/foucault1.pdf/> [28.02.2016].

Gaiman, N. (2015) Neverwhere: Author's Preferred Text, William Morrow, New York.

Gomel, E. (2014): Narrative Space and Time. Representing Impossible Topologies in Literature, Routledge, New York.

KAIKA, M. and E. SwYngedouw (2005): «Fetishizing the Modern City. The Phantasmagoria of Urban Technological Networks» in N. Fyfe and J. Kenny (eds.), The Urban Geography Reader, Routledge, Oxon.

KRÄTKE, S. (2006): «Global Media Cities: Major Nodes of Globalising Culture and Media Industries» in N. Benner and R. Keil (eds.), The Global Cities Reader, Routledge, London and New York.

Lutwack, L. (1984): The Role of Place in Literature, Syracuse University Press, Syracuse.

MayHew, H. (1851): London Labour and the London Poor, George Woodfall and Son, London [online], available from https: / / archive.org/details / cu31924092592751 / [28.02.2016].

McLaughlin, J. (2000): Writing the Urban Jungle: Reading Empire in London from Doyle to Eliot, University Press of Virginia, Charlottesville and London.

Mendelsohn, F. (2008): Rhetorics of Fantasy, Wesleyan University Press, Middletown, CT.

Nikolajeva, M. (2003): «Fairy Tale and Fantasy: From Archaic to Postmodern», Marvels E Tales, vol. 17, no. 1, pp. 138-156. <https:/ / doi.org/10.1353/mat.2003.0014>

Quiller-Couch, A. T. (1918): The Oxford Book of English Verse, 1250-1900, Clarendon Press, London, Edinburgh, Glasgow, New York.

Roger, S. (2013): «How Britain changed under Margaret Thatcher. In 15 charts», The Guardian, Monday, April, the $8^{\text {th }}, 2013$ [online], available from https:/ / www. theguardian.com/ politics / datablog/2013/apr/08/britain-changed-margaret-thatcher-charts / [26.10.2016].

United NAtions, Department of Economic and Social Affairs (2014): World Urbanization Prospects. The 2014 Revision. [online], available from https:/ / esa.un.org/ unpd/ wup/publications / files / wup2014-highlights.Pdf/ [28.02.2016]

Westrhal, G. (ed.) (2005): The Greenwood Encyclopedia of Science Fiction and Fantasy: Themes, Works, and Wonders,vol. 1-2, Greenwood Press, Westport.

Wolfe, G. (1999): Free Live Free, Tom Doherty Associates LLC, New York. 